\title{
Peran bimbingan konseling islam bagi pengembangan moral siswa madrasah ibtidaiyah
}

\author{
Farinka Nurrahmah Azizah a,1, ${ }^{\text {, Indah Wahyuningsiha,2 }}$
}

a STAINU Temanggung, Jawa Tengah, Indonesia;

*1 farinkanurrahmah azizah@gmail.com; 2 lintangwgs@gmail.com;

Received:

Revised:

Accepted:

KATAKUNCI

Bimbingan Konseling Islam Pengembangan Moral, Siswa Madrasah Ibtidaiyah.

\section{KEYWORDS}

Islamic Counselling, Moral Development, Madrasah Ibtidaiyah
Artikel ini menjelaskan peran bimbingan konseling islam bagi pengembangan moral siswa Madrasah Ibtidaiyah. Pendekatan penelitian berupa kualitatif deskriptif. Teknik pengumpulan data menggunakan wawancara, observasi dan dokumentasi. Penelitian dilakukan di MI Maarif Asmaul Husna, Kemloko, Kranggan, Temanggung dengan narasumber guru kelas dan guru mapel yang ditunjuk sebegai guru BK Islam. Adapun rumusan masalah dalam artikel ini adalah (1) apa peran bimbingan konseling islam bagi perkembangan moral siswa madrasah ibtidaiyah (2) bagaimana implementasi bimbingan konseling islam bagi pengembangan moral siswa MI dan (3) Apa kendala dalam melaksanakan bimbingan konseling islam bagi pekembangan moral siswa madrasah ibtidaiyah. Hasil dari penelitian ini menunjukkan bahwa terdapat peran bimbingan konseling Islam bagi pengembangan moral peserta didik di Madrasah Ibtidaiyah sehingga bimbingan konseling islam merupakan hal yang urgent diadakan di madrasah ibtidaiyah.

\section{The role of Islamic counseling guidance for the moral} development of madrasah ibtidaiyah students

This article explains the role of Islamic counselling for moral development of Madrasah Ibtidaiyah students. The research approach is qualitative descriptive. Data collection techniques are using interviews, observation and documentation. The research was conducted at MI Maarif Asmaul Husna, Kemloko, Kranggan, Temanggung with resource persons were class teachers and subject teachers who were appointed as BK Islamic teachers. Formulation problems in this article are (1) what is the role of Islamic counselling for Madrasah Ibtidaiyah students moral development (2) how is the implementation of Islamic counselling for the moral development of MI students and (3) What are the obstacles in carrying out Islamic counselling guidance for the moral development of madrasah ibtidaiyah students. The results of this study indicate that there is a role for Islamic counselling for moral development of students in Madrasah Ibtidaiyah so that Islamic counselling is an urgent matter held in Madrasah Ibtidaiyah.

This is an open-access article under the CC-BY-SA license.

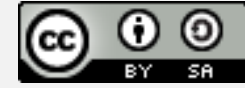




\section{Pendahuluan}

Seyogyanya, pendidikan ada untuk melaksanakan usaha sadar dan terencana untuk pengembangan potensi siswa baik dari segi kognitif, keyakinan, nilai maupun moral secara optimal. Idealnya, sekolah dan guru memang harus memenuhi kebutuhan peserta didik untuk pencapaian perkembangan diri siswa. Tak terkecuali pada siswa Madrasah Ibtidaiyah yang berada pada rentang usia 7-11 tahun, banyak kompetensi yang harus dikembangkan antara lain pada aspek fisik, motorik, psikososial, bahasa dan moral.

Dalam hal ini, sinergi antara semua pihak sekolah dalam meningkatkan potensi siswa terutama dalam pembentukan moral siswa sangat dibutuhkan, tidak cukup hanya dilakukan oleh guru kelas maupun guru mata pelajaran. Komponen sekolah seperti kepala sekolah juga guru bimbingan konseling merupakan pihak yang harus turut serta dalam mengembangkan moral siswa di madrasah ibtidaiyah.

Dasar penanaman moral oleh seluruh komponen sekolah selaras dengan pendapat John Mahoney bahwa "Memasukkan seluruh kegiatan sekolah termasuk kegiatan ektra kurikulumnya adalah dalam rangka pendidikan nilai moral. Kegiatan di dalam maupun di luar kelas, harus mengupayakan muatan nilai-nilai moral yang berguna bagi pembentukan kepribadian peserta didik sebagai bekal hidup bermasyarakat masa kini dan masa datang. Pendeknya seluruh kegiatan di sekolah yang menjadi tanggung jawab sekolah diupayakan memuat pendidikan nilai moral"

Terkait dengan pengembangan moral, banyak kasus degradasi moral yang telah terjadi di Indonesia, tak terkecuali ranah Pendidikan. Penanaman moral harus dipupuk sedari kecil, karena bila tidak ditangani secara intensif dikhawatirkan akan berakibat buruk baik untuk siswa sendiri maupun orang lain yang secara tidak langsung berhubungan dengan kasus degradasi moral sendiri.

Kemerosotan moral sendiri juga dirasakan oleh guru Madrasah ibtidaiyah Asmaul Husna. Secara spesifik, permasalahan moral ini tidak bisa dihindari lagi karena pengalaman dan pengetahuan tentang moral siswa masih tergantung kepada orang tua maupun lingkungan masyarakat sekitar. Kasus mengenai ketidakjujuran, ketidaksopanan, perilaku buruk dan pelanggaran peraturan masih banyak dilakukan siswa terutama siswa dengan penanaman moral awal dari keluarga dan masyarakat sekitar yang buruk.

Implementasi pembelajaran moral di Madrasah Ibtidaiyah dimulai dari penataan perilaku sehingga sesuai dengan peraturan sekolah dan penggunaan bahasa yang baik dan benar dilanjutkan dengan penanaman nilai-nilai moral yang berguna untuk pengembangan moral siswa.

Hasil dari wawancara awal menyebutkan, bahwa banyak siswa yang melanggar aturan atau tak tahu cara bertingkah laku kepada orang yang lebih tua. Contonya dari segi pemaikaian Bahasa, terutama di daerah Jawa yang harus mempunyai kasta Bahasa. Siswa Maarif Asmaul Husna ada yang masih menggunakan kata "kowe" di sekolah, padahal hal ini merupakan hal yang tabu bila diucapkan kepada orang yang lebih tua. Meski Pendidikan moral selalu diselipkan pada pembelajaran PKn maupun Pendidikan Agama Islam, namun tidak dapat dipungkiri hal spesifik seperti masalah tata Bahasa tersebut diperlukan guru bimbingan konseling. Selain itu, pelanggaran aturan sekolah yang merupakan salah satu tanda ketidakpatuhan kepada norma yang tidak bisa sepenuhnya ditangani oleh guru kelas. Menurut wawancara awal, guru di madrasah cukup sibuk dengan tugas mengajar dan administasi sehingga pengembangan moral tidak dapat dilakukan secara optimal. Di sinilah guru BK Islam berperan besar dalam membimbing anak untuk menjalankan peraturan di yang ada di sekolah.

Sebenarnya peran guru BK diberikan kepada konselor yaitu seorang yang telah lulus S1 jurusan bimbingan konseling sesuai dengan Permendiknas No. 27 Tahun 2008 mengenai Standar Kualifikasi Akademik dan Kompetensi Konselor. Sayangnya, di Madrasah Ibtidaiyah 
yang juga merupakan rumpun satuan pendidikan dasar terdapat pengecualian mengenai peraturan tersebut. Peran guru BK dapat diberikan kepada guru kelas maupun guru yang ditunjuk sebagai konselor. Pada kasus di Madrasah Ibtidaiyah Asmaul Husna sendiri, guru BK biasanya diampu oleh guru agama dan guru kelas. Bimbingan konseling yang diberikan lebih banyak berdasarkan asas-asas keislaman sesuai dengan ajaran yang dibawa oleh Muhammad S.A.W sehingga lebih cocok disebut dengan bimbingan konseling islam.

Pengembangan moral melalui BK islam sendiri selaras dengan fungsi yang diemban bimbingan konseling islam itu sendiri. Tiga fungsi utama tersebut adalah preventif; pencegahan peserta didik untuk melakukan masalah, fungsi kuratif; yakni memperbaiki atau membantu peserta didik untuk memiliki sifat problem solving ke depannya dan fungsi developmental yaitu mengembangkan serta memelihara kebaikan yang telah ada diri siswa sehingga menjadi lebih baik dan bermoral.

Setelah bahasan yang telah dijabarkan, maka didapatkan rumusan masalah yang akan difokuskan dalam artikel sebagai berikut:

a. Apa peran bimbingan konseling Islam terhadap perkembangan moral peserta didik?

b. Bagaimana implementasi bimbingan konseling Islam terhadap perkembangan moral peserta didik madrasah ibtidaiyah?

c. Apa saja kendala yang terjadi dalam bimbingan konseling islam terhadap perkembangan moral peserta didik madrasah ibtidaiyah?

\section{Metode}

Pendekatan penelitian berupa kualitatif deskriptif. Teknik pengumpulan data menggunakan wawancara, observasi dan dokumentasi. Adapun sumber didapat dari guru kelas dan guru agama yang ditunjuk menjadi guru bimbingan konseling islam di sekolah sebanyak 7 orang, terdiri dari 6 guru kelas dan satu guru agama yang ditunjuk sebagai guru khusus bimbingan konseling islam. Data yang diambil berupa pelaksanaan bimbingan konseling islam di madrasah Ibtidaiyah sehingga berpengaruh terhadap pengembangan moral siswa dan kendala dalam pelaksanaannya di madrasah ibtidaiyah.

\section{Hasil dan Pembahasan}

\section{Pengembangan Moral pada Peserta Didik Madrasah Ibtidaiyah}

Pengembangan sendiri memiliki definisi yang kompleks. Proses kematangan dan pengalaman yang bersifat kualitatif dan kuantitatif sehingga memunculkan perubahan yang progresif merupakan salah satu definisi perkembangan yang digagas oleh Hurlock. Berbeda dengan konsep pertumbuhan, perkembangan tidak memiliki akhir dan terus mengalami progress selama manusia tersebut hidup di dunia.

Sedangkan moral didefinikasikan sebagai perilaku individu yang sesuai dengan peraturan yang berlaku di masyarakat sekitar. Manfaat pengembangan moral sendiri agar manusia lebih dapat menjalani hidup secara lebih damai dan selaras dengan lingkungan sekitar. Baik dan buruknya perkembangan moral seseorang berkaitan erat dengan norma dan nilai yang ada di lingkungan. Peran lingkungan keluarga dan lingkungan sosial yang lebih luas di luar keluarga menjadi pusat dari pelajaran moral anak yang akan membawa anak untuk melalui setiap tahap perkembangan moralnya

Penanaman nilai moral bertujuan menumbuhkan nilai-nilai moral sejak dini, karena apabila terlambat ditanamkan akan menjadikan kendala bagi individu untuk menentukan sikap ke depannya. Diharapkan dengan penanaman moral sejak dini, siswa dapat menjadikan nilai yang baik sebagai kebiasaan yang tertanam dalam cara pandang dan sikap hidup.

Adapun aspek pengembangan moral pada peserta didik madrasah ibtidaiyah, Piaget mempunyai pandangan bahwa pengenalan nilai dan perilaku pada anak usia dasar pada awalnya berupa "paksaan". Tingkat kognitif peserta didik saat itu belum memahami makna 
mengapa beberapa hal boleh dilakukan sementara hal yang lain tidak dapat dilakukan. Namun, seiring dengan perkembangan kognitifnya kepatuhan anak terhadap peraturan keluarga akan meluas kepada peraturan masyarat negara. Terkhusus pada pengembangan moral, Piaget menjelaskan usia 7-11 tahun sebagai usia urgent anak-anak mengembangkan perilaku moral mereka dengan meniru atau mendapat ide dari masukan orang dewasa.

Piaget pun membagi tahap perkembangan moral menjadi dua, yaitu moralitas heteronom dan moralitas otonom. Moralitas heteronom terjadi pada rentang usia 4 sampai 7 tahun, saat anak memahami keadilan dan peraturan sebagai sesuatu yang berada di luar kendali manusia dan bersifat mutlak sehingga penilaian suatu tindakan melihat pada konsekuensi yang akan terjadi. Moralitas otonom terjadi pada usia 10 tahun ke atas, yaitu tahap saat anak mengetahui bahwa peraturan dibuat oleh manusia sehingga dalam menilai suatu tindakan harus mempertimbangkan niat pelaku dan konsekuensinya. Anak usia SD antara 7 sampai 10 tahun berada pada masa transisi dari moralitas heteronom ke moralitas otonom sehingga pada moralitas anak akan ditemukan kedua karakteristik perilaku pada kedua tahap tersebut. Maka dalam hal ini guru selaku guru bimbingan konseling Islam harus memahami kharakter dan keadaan kognisi anak untuk memberikan layanan yang seusai kepada siswa madrasah

Ibtidaiyah

Perbedaan pola asuh maupun lingkungan masyarakat juga dinilai mengakibatkan standar moral siswa yang bervariasi. Namun dapat disimpulkan beberapa faktor yang mempengaruhi pengembangan moral antara lain:

a. Faktor hereditas, yaitu faktor warisan anak itu sendiri. Faktor hereditas sendiri dapat diartikan sebagai faktor intern yang mempengaruhi moral anak ke depannya. Seperti kecerdasan, watak dan motivasi yang ada dalam diri anak itu sendiri.

b. Faktor lingkungan, pola asuh orang tua, pengaruh teman sebaya dan lingkungan masyarakat berperan penting dalam pembentukan norma anak. Penelitian menunjukkan anak dengan pola asuh orang tua yang lebih minim dalam pengembangan norma dibanding yang pola asuh otoriter maupun demokratis8

c. Faktor gabungan, adalah faktor gabungan di antara keduannya, bahwa lingkungan memang menyumbang proses pengembangan moral siswa, namun pada akhirnya siswa sendiri yang akan memilah mana moral yang baik dan yang buruk.

Adapun nilai-nilai moralitas dan budi pekerti yang harus ditanamkan pada jenjang madrasah ibtidaiyah adalah sebagai berikut: “1). Nilai Religius, 2). Nilai Sosialitas, 3). Nilai Gender, 4). Nilai Keadilan, 5). Nilai Demokrasi, 6). Nilai Kejujuran, 7). Nilai Kemandirian, 8). Nilai Daya juang, 9). Nilai Tanggung jawab, dan 10). Nilai Penghargaan terhadap lingkungan . Kesepuluh nilai ini mutlak harus diterapkan para guru BK Islam untuk dapat mengembangkan moral siswa dengan optimal.

\section{Implementasi Bimbingan Konseling Islam Bagi Pengembangan Moral}

Secara etimologis, bimbingan berasal dari kata "guidance" yang berasal dari kata kerja "to guide" yang mempunyai arti menunjukkan atau menuntun. Sedangkan konseling berasal dari bahasa latin yaitu consilium atau memahami. Sehingga bimbingan konseling merupakan pemberian bantuan kepada anak didik oleh konselor dengan tujuan pengarahan diri dan mengembangkan kejiwaannya.10

Sedangkan istilah Bimbingan konseling islam sendiri adalah bimbingan konseling yang beasaskan ajaran-ajaran islam beradasarkan aturan Allah SWT dan nabi Muhammad, SAW. Bimbingan konseling islam mengembangkan siswa kepada fitrah islam sehingga kebahagiaan datang di dunia dan akhirat. Konseling dalam bimbingan konseling islam juga bertugas sebagai pengingat ajaran Allah SWT untuik kemudian diaplikasikan pada kehidupan seharihari;

Erhamwilda menyebutkan bahwa tujuan Bimbingan dan Konseling Islam bagi individu 
adalah:

a. Dapat memahami dan menyadari tindakan yang terbaik demi mencapai kehidupan bahagia baik di dunia maupun di akhirat.

b. Memiliki kesadaran diri, sehingga memahami kekhususan atau keunikan dalam dirinya.

c. Mengembangankan sikap positif.

d. Membuat pilihan secara tepat dan sehat.

e. Menghargai perbedaan dan pendapat orang lain.

f. Mengembangkan rasa tanggung jawab.

g. Memupuk hubungan antar pribadi dan dapat menyelesaikan konflik.

h. Membuat keputusan secara efektif

Sementara di Madrasah Ibtidaiyah yang notabenenya adalah Pendidikan dasar plus dengan tambahan materi keagamaan dirasa pas untuk melaksanakan bimbingan konseling islam di instansi sekolahnya. Adapun layanan pada bimbingan konseling islam yang dilaksanakan pada MI Ma’arif Asmaul Husna meliputi;

a. Layanan Orientasi, instansi madrasah mengenalkan lingkungan dan fasilitas sekolah,serta peraturan dan hak-hak serta layanan BK Islam untuk membantu siswa menyelesaikan masalah, termasuk apabila ada permasalahan tentang pengembangan moral.

b. Layanan Informasi, dalam aspek pengembangan moral, guru BK Islam mengenalkan nilainilai sosial. adat istiadat dan aturan yang berkembang di masyarakat. Sehingga anak mampu menyelaraskan perilaku dan sikapnya dengan nilai masyarakat selaras dengan ajaran Islam. Selain itu tata tertib sekolah, cara berperilaku, sopan santun dan tata krama di sekolah juga dikenalkan untuk dipatuhi anak berkaitan dengan pengembangan moral siswa baik di lingkungan sekolah maupun di masyarakat.

c. Layanan Penguasaan Konten. Guru dalam layanan ini membantu anak untuk menguasai sebuah konten. Terutama yang menyangkut tentang kompetensi atau kebiasaan yang dapat berguna di sekolah, keluarga dan masyarakat.

d. Layanan individu. MI Maarif Asmaul Husna menggunakan pendekatan individu pada kasus anak yang memerlukan penanganan lebih intensif. Anak dipantau terus menerus untuk memperbaiki perilakunya sesuai dengan fungsi bimbingan konseling yang bersifat developmental. Seperti pada proses norma berperilaku dan bercakap kepada orang yang lebih tua, layanan face to face dirasa paling efektif untuk memperbaiki perilaku anak yang salah. Tahap pelayanannya berupa pembukaan, penjelasan baru kemudian penggubahan tingkah laku. Kendala dalam melakukan hal ini adalah waktu yang terbatas sehingga tidak bisa memfasilitasi pengembangan moral anak secara individu.

e. Layanan kelompok, menggunakan pendekatan kelompok yang mempunyai permasalahan yang dianggap sama. Layanan ini juga dapat dilaksanakan secara klasikal dan diselipkan pada beberapa materi pembelajaran di sekolah terutama mata pelajaran agama, namun MI Maarif Asmaul Husna belum melakukan layanan klasikal karena Bimbingan Konseling Islam belum masuk pada muatan lokal sekolah.

f. Layanan Konsultasi, MI Maarif Asmaul Husna juga membuka layanan konsultasi yang di dalamnya juga dapat mencakup pada proses pengembangan moral siswa. Jadi, siswa dapat berkonsultasi mengenai permasalahan menerapkan norma, atau sekedar mengetahui mana norma yang baik dan mana norma yang buruk sesuai dengan lingkungan di sekitar. Pada praktiknya nilai nilai moral yang ada dalam layanan bimbingan konseling di MI Kemloko diselipkan beberapa nilai-nilai, antara lain:

1) Nilai Religius: mengamalkan ajarannya, dalam praktiknya siswa diajarkan untuk berjamaah pada shalat dhuhur, membaca asmaul husna sebelum mulai pembelajaran dan diajarkan untuk selalu mengkaji ajaran islam baik melalui bimbingan konseling baik melalui sisipan pelajaran dan bimbingan pribadi.

2) Nilai Sosialitas: Siswa diajarkan untuk berempati kepada lingkungan sekitar, membantu sesama teman dan setiap hari jumat ada sedekah untuk membantu orang yang tidak mampu. 
3) Nilai Gender: Guru mengajarkan bahwa terdapat perbedaan peran antara wanita dan pria menurut ajaran Islam, seperti kewajiban untuk menutup aurat seluruh tubuh kecuali muka dan telapak tangan bagi perempuan dan sebatas pusar hingga lutut kaki bagi lelaki. Meski untuk meraih prestasi dan menuntut ilmu tidak ada halangan bagi keduanya untuk menuntut ilmu.

4) Nilai Keadilan: siswa dihimbau tidak melakukan kekerasan atau tindak bulliying baik psikis maupun verbal. Guru juga tidak membeda-bedakan siswa dalam menerapkan peraturan.

5) Nilai Demokrasi: siswa diajarkan untuk bebas menyuarakan pendapat namun dalam konteks pria dan wanita dan dengan Bahasa yang baik dan membangun, kebebasan itu diberlakukan sama antara pria dan wanita. Dalam praktiknya, siswa dituntun untuk aktif berpendapat dan mengeluarkan keinginannya baik ketika pembelajaran maupun di luar konteks pembelajaran.

6) Nilai Kejujuran: siswa senantiasa diajarkan untuk bersifat sidiq, yaitu dapat dipercaya, hal ini dapat dicontohkan untuk mengerjakan ulangan dan tugas sekolah sendiri, tidak menyontek teman atau mencontoh pekerjaan teman-teman.

7) Nilai Kemadirian: Siswa diajarkan untuk meraih kemandirian semenjak dini. Pada kelas rendah, siswa dibimbing untuk mampu mempersiapkan perlengkapan sekolah secara mandiri, sementara pada kelas tinggi siswa dituntut untuk mampu menyelesaikan tugas individu secara mandiri.

8) Nilai Daya Juang: Siswa diajarkan untuk menjadi pribadi yang teguh dan memiliki daya juang yang tinggi sesuai cita-citanya dengan tidak melupakan doa di setiap perjuangannya. Siswa juga dibimbing untuk memilih ekstrakulikuler yang disenangi untuk dapat memperjuangkan cita-citanya. Selain itu, siswa juga diajarkan untuk tak patah semangat untuk tolabul ilmi (menuntut ilmu) meski dengan keterbatasan dari segi biaya maupun fasilitas hidupnya.

9) Nilai Tanggung Jawab: Siswa diajarkan untuk dapat memikul tanggung jawab yang diamanahkan pada siswa, dalam prakteknya siswa harus berdisiplin pada piket dan mengumpulkan tugas secara tepat waktu.

10) Nilai Penghargaan terhadap lingkungan: Lingkungan adalah sebagaimana ajaran islam, bahwa manusia sebagai khalifah, dan seyogyanya sebagai pemimpin yang baik harus mampu menjaga kelestarian lingkungan. Dalam praktiknya siswa diajarkan untuk membuang sampah di tempat sampah menerapkan jargon "kebersihan Sebagian dari iman", membawa bibit tanaman untuk ditanam di sekolah dan tugas piket membersihkan kelas.

Secara singkat, guru mengakui layanan bimbingan Islam ini mengakomodasi siswa untuk pengembangan moral, karena setelah mendapat layanan BK Islam siswa jadi lebih tahu mana hal yang baik dan buruk serta yang boleh di lakukan maupun tidak. Nilai moral yang ditanamkan melalui bimbingan konseling islam pun dirasa lebih efektif untuk dilaksanakan daripada hanya mengandalkan Pendidikan karakter lewat pembelajaran di kelas. Permasalahan seperti pelanggaran peraturan dan kesalahan bertata Bahasa seperti lebih dapat diatasi dengan bimbingan konseling islam terutama dalam layanan individual,

Selanjutnya, penemuan di lapangan menemukan bahwa terdapat peran bimbingan konseling islam terhadap pengembangan moral pada siswa madrasah ibtidaiyah sesuai dengan pendapat Piaget bahwa anak mendapatkan proses penanaman moral pada faktor di sini adalah guru pembimbing BK di madrasah ibtidaiyah. Setelah mendapat layanan bimbingan konseling islam, anak dirasa lebih mampu membedakan hal yang baik dan buruk untuk dilakukan di baik di lingkungan sekolah maupun di masyarakat sekitar. 


\section{Kendala Pengembangan Moral melalui Bimbingan Konseling Islam}

Sebagai tambahan, peneliti merasa perlu untuk mencari kendala yang terjadi pada pengembangan moral melalui bimbingan konseling islam di MI Maarif Asmaul Husna, namun secara garis besar terdapat lima aspek yang di dapat setelah wawancara dengan guru BK dalam melaksanakan bimbingan konseling islam di madrasah ibtidaiyah, yaitu: a) Kurangnya ilmu pengetahuan tentang bimbingan konseling islam karena bukan merupakan lulusan prodi BK. Meski pernah mendapat dasar bimbingan konseling islam melalui mata kuliah di perguruan tinggi, namun dirasa belum cukup untuk melayani bimbingan konseling islam anak secara optimal.

a. Kharakteristik anak yang beragam yang juga membutuhkan perlakuan yang beragam. Beberapa siswa dapat melakukan perubahan perilaku secara langsung, sementara yang lain perlu waktu yang lebih lama dan dilakukan layanan BK Islam secara terus menerus.

b. Kerjasama antar komponen seperti orang tua wali dan lingkungan sekitar, seperti telah dijelaskan sebelumnya bahwa beberapa faktor kurangnya moral anak disebabkan karena keacuhan orang tua dan lingkungan masyarakat sekitar terhadap perkembangan moral anak.

c. Kurangnya pihak yang dapat dijadikan rujukan bagi anak yang mempunyai permasalahan moral yang tidak bisa ditangani pihak sekolah (layanan alih tangan kasus), pada penanganan perilaku menyimpang anak terhadap norma, terkadang harus ada pihak yang lebih kompeten sebagai rujukan pemecahan masalah seperti psikolog maupun psikiater, namun pihak sekolah dirasa belum mampu untuk berkolaborasi dengan dikarenakan berbagai kendala.

Meski begitu, kendala tersebut dirasa masih bisa dicari pemecahan masalah ke depannya, sehingga layanan bimbingan konseling di sekolah tetap harus dapat dilaksanakan untuk proses pengembangan potensi siswa secara optimal.

\section{Simpulan}

Berdasarkan hasil penelitian, dapat disimpulan bahwa pengembangan moral pada siswa Madrasah Ibtidaiyah merupakan hal yang urgent dan harus difasilitasi oleh setiap komponen sekolah termasuk oleh guru BK. Madrasah Ibtidaiyah yang notabenenya adalah sekolah dasar dengan tambahan muatan keagamaan dirasa paling cocok diterapkan bimbingan konseling Islam. Bimbingan Konseling Islam adalah salah satu komponen yang dipandang mampu untuk meningkatkan moralitas siswa.

Pengembangan moral ini membutuhkan sinergi dari semua komponen sekolah salah satunya adalah guru Bimbingan konseling islam, yang di madrasah ibtidaiyah dilakukan oleh guru kelas yang merangkap menjadi guru Bimbingan konseling islam atau salah satu guru yang ditunjuk menjadi guru bimbingan konseling islam.

Implementasi pembelajaran moral di Madrasah Ibtidaiyah dimulai dari penataan perilaku sehingga sesuai dengan peraturan sekolah dan penggunaan bahasa yang baik dan benar. Setelah itu dilanjutkan dengan penanaman nilai-nilai moral yang berguna untuk pengembangan moral siswa.

Terkait layanan yang diberi meliputi layanan orientasi, layanan informasi, layanan penguasaan konten, layanan individu, layanan kelompok, layanan Konsultasi. Nilai moral secara spesifik pun yang ditanamkan sesuai dengan pendapat Suparno yaitu nilai religious, nilai demokrasi, nilai keadilan, nilai gender, nilai kejujuran, nilai daya juang , nilai tanggung jawab dan nilai penghargaan terhadap lingkungan.

Kendala yang ada dalam pengembangan moral pada Madrasah Ibtidaiyah adalah: (1) Kurangnya ilmu pengetahuan tentang bimbingan konseling islam karena bukan merupakan lulusan prodi BK, (2) Kharakteristik anak yang beragam yang juga membutuhkan perlakuan yang beragam. Beberapa siswa dapat melakukan perubahan perilaku secara langsung, sementara yang lain perlu waktu yang lebih lama dan dilakukan layanan BK Islam secara 
terus menerus, (3) Kerjasama antar komponen seperti orang tua wali dan lingkungan sekitar, seperti telah dijelaskan sebelumnya bahwa beberapa faktor kurangnya moral anak disebabkan karena keacuhan orang tua dan lingkungan masyarakat sekitar terhadap perkembangan moral anak. (4) Kurangnya pihak yang dapat dijadikan rujukan bagi anak yang mempunyai permasalahan moral yang tidak bisa ditangani pihak sekolah (layanan alih tangan kasus).

Jadi, secara garis besar, hal ini membuktikan bahwa bimbingan konseling islam sangat berpengaruh bagi perkembangan moral siswa madrasah ibtidaiyah. Pelayanan BK Islam yang baik dapat mengoptimalkan potensi moral siswa yang kelak sangat berguna bagi kemaslahatan siswa sendiri maupun masyarakat sekitar.

\section{Daftar Pustaka}

Ahmad Muhaimin Azzet (2011). Bimbingan Konseling di Sekolah. Yogyakarta: Arruz Media.

Anonim (2004). Bimbingan dan Konseling dalam Islam. Yogyakarta: UII Press

Alomari, Jamal F, M. 2011. "Moral Education". Macrothink Institutde Jurnal International Education". Vol

3. No.2: E18. Diakses pada 27 Juni 2020 pada pukul 19.00 WIB

(http://dx.doi.org/10.5296/ije.v3i2.1257)

Daryanto dan Muhammad Farit. (2015). Bimbingan Konseling: Panduan Guru BK dan Guru Umum. Yogyakarta: Gava Media.

Departemen Pendidikan Nasional. (2008). Bimbingan dan Konseling di Sekolah: Modul untuk Pengawas Sekolah. Jakarta: Direktorat Tenaga Kependidikan Direktorat jenderal peningkatan Mutu Pendidik dan Tenaga Kependidikan.

Erhamwilda. (2008). Konseling Islami, Yogyakarta: Graha Ilmu.

Hosnan. (2016). Psikologi Perkembangan Peserta didik. Bogor: Penerbit Ghalia Indonesia.

Hurlock, B. Elizabeth. (1990). Psikologi Perkembangan: Suatu Pendekatan Sepanjang Rentang Kehidupan. Jakarta: Erlangga.

Rima Trianingsih, 2016. "Pengantar Praktik Mendidik Anak Usia Sekolah Dasar". Jurnal AL IBTIDA 3 (2):

197-211. Diakses pada 29 Juni 2020 WIB.

(http://www.syekhnurjati.ac.id/jurnal/index.php/ibtida/article/view/880/692)

Ruslan, dkk. 2016. "Penanaman Nilai-Nilai Moral pada Siswa" Jurnal Ilmiah Mahasiswa Prodi PGSD WIB.

FKIP Unsyiah Volume 1 Nomor 1, 68-77 Agustus 2016. D Diakses pada 7 Juli 2020

(https://media.neliti.com/media/publications/187368-ID-penanaman-nilai-nilai-moralpada-siswad.pdf)

Satrock, J. W (1996). Adolescence, Edisi Keenam (Kristiaji, W. C \& Sumiharti, Y, Ed). Adelar, S. B \&

Saragih, S. 2003. Jakarta: Penerbit Erlangga 